\title{
An Assessment of Stumpage Price and the Price Index of Chinese Fir Timber Forests in Southern China Using a Hedonic Price Model
}

\author{
Hong Chen ${ }^{1,2,3 \oplus}$, Zhongsheng He ${ }^{1,3} \oplus$, Wei Hong ${ }^{1}$ and Jinfu Liu ${ }^{1,2,3, *}$ \\ 1 College of Forestry, Fujian Agriculture and Forestry University, Shangxiadianlu 15, Fuzhou 350002, China; \\ chenhong@m.fafu.edu.cn (H.C.); jxhzs85@fafu.edu.cn (Z.H.); fjhongwei@126.com (W.H.) \\ 2 College of Computer and Information Sciences, Fujian Agriculture and Forestry University, \\ Shangxiadianlu 15, Fuzhou 350002, China \\ 3 Key Lab of Ecology and Resources Statistics of Fujian Colleges, Shangxiadianlu15, Fuzhou 350002, China \\ * Correspondence: fjlif@fafu.edu.cn; Tel.: +86-15359119967
}

Received: 28 February 2020; Accepted: 9 April 2020; Published: 12 April 2020

\begin{abstract}
Research Highlights: Stumpage price is the most important factor affecting the value of forests. Therefore, an understanding of the factors affecting stumpage prices and trends is critical for effective forest management. Background and Objectives: Chinese fir is the most important fast-growing timber species in China, it is also the tree species with the largest trading volume in the stumpage markets of Southern China. The aim of this study was to analyze the determinants and trends of stumpage prices for Chinese fir timber forests. Materials and Methods: Data on 928 sales of Chinese fir timber forests transacted between 2007 and 2016 were gathered from the stumpage markets in Southern China. We analyzed the relationship between stumpage prices and sales characteristics using the hedonic price method (HPM) and measured the stumpage price index with a dummy time hedonic index. Results: (1) The double logarithmic form of the HPM yielded a more accurate estimate than the semi logarithmic form. The $\mathrm{R}^{2}$ ad values in the nine annual prediction models were all above $80 \%$. Stock volume made the greatest contribution to stumpage price, followed by stand age. Stand area had no significant impact on the stumpage price. (2) Stumpage prices of Chinese fir timber forests fluctuated greatly, especially in 2010 and 2015 when the sequential price indexes were $180.01 \%$ and $74.95 \%$, respectively. Taking 2007 as the baseline, we calculated the base price index in 2016 to be $197 \%$, with an average annual growth rate of $7.82 \%$. (3) The stumpage market was associated with a higher degree of risk than the timber market. Conclusions: Our findings provide valuable inputs that can guide and facilitate the Chinese government's efforts to optimize resource allocation and standardize the stumpage market.
\end{abstract}

Keywords: stumpage price; Chinese fir timber forests; hedonic price method; dummy time hedonic index; Southern China

\section{Introduction}

The prices of stumpage (standing timber) are often considered to be residual, referring to the value that remains after adjusting for profits and deducting all costs from the value of the lumber at the mill [1]. Stumpage prices critically influence the value of forest assets and are consequently a crucial factor determining a forest owner's decision to sell a forest. Therefore, it is pertinent to model and forecast stumpage prices. Previous studies that examined actual stumpage prices paid in individual sales have mainly focused on two aspects: the time series of stumpage prices [2-9] and the factors influencing stumpage prices [10-18]. The former set of studies were aimed at examining the dynamics of stumpage markets, whereas the latter group sought to investigate the relationship between stumpage 
prices and factors such as harvestable volume density, the total area involved in the sale, and the diameter of the trees. A well-regulated and active market for stumpage and the availability of complete datasets are necessary prerequisites for analyses of stumpage prices. Consequently, such studies have been conducted mostly in developed countries (e.g., the United States, United Kingdom, and Canada), with a limited number of studies conducted in developing and less developed countries. The main purpose of this study was to ascertain the determinants of stumpage prices in China's forestry exchange market. The reform of China's collective forest rights system at the beginning of the twenty-first century $[19,20]$ was based on the premise that the nature of the ownership of collective forest land and the use of forest land would remain unchanged, but the right to use forest land and the ownership of trees would be allocated to individual forest farmers. The Chinese government has encouraged the trade of forest rights to optimize the allocation of forest resources. To encourage further transactions of forest rights, provincial, or regional forestry exchange markets have been rapidly established. Ongoing improvements of these markets and the promotion of forest-based reforms have led to the expansion of the trade in forestry exchange markets. However, studies on the determinants of stumpage prices within China's forestry exchange markets remain limited.

The hedonic price method (HPM) has been widely used in studies of commodity prices [21-32], and its use is particularly appropriate in contexts that entail heterogeneous production inputs whose underlying production characteristics demonstrate significant variations. Given differences in forest characteristics, including component tree species and their quality, size, or volume, forest assets are evidently heterogeneous commodities. From the perspective of wood producers, a forest is a typical heterogeneous product, entailing complex inputs evidencing diverse characteristics.

Some researchers outside China have applied the HPM to study forest assets or services. Escobedo et al. [33] conducted a valuation of an urban forest ecosystem service by integrating an explanatory hedonic regression model with randomly measured field data on trees, shrubs, and turf compiled for four cities in the US state of Florida during the period 2006-2009. Puttock et al. [34] estimated the price of standing timber in the southwestern part of the Canadian province of Ontario using this method. Their results indicated that volume, species composition, tree size, timber quality, and distance to the purchasing mill were important characteristics influencing stumpage prices. Aronsson et al. [35] found that the market value of the stumpage per hectare was negatively related to the area of its occurrence and positively related to the stock volume. In addition, the incomes of sellers and buyers respectively have positive and negative effects. Leefers et al. [36], who estimated stumpage prices in the Lake States forests in the United States, found that stumpage prices were aligned with the identities of individual species. In a study of 4824 standing timber sales transactions conducted during the period 2008-2012, Kolis et al. [37] analyzed the relationship between stumpage prices and sales-specific factors. Their findings revealed the impacts of seasonal harvest restrictions, sales volumes, timber assortment, and forest damage on stumpage prices. Kim et al. [38], who analyzed the relationship between pine stumpage prices and associated sales characteristics, found that increases in these prices corresponded to increases in the sales volumes, contract length, bid sales, and the number of bidders. Moreover, a positive relationship existed between higher timber grades and better market and logging conditions and stumpage prices.

The differences between predictive models developed by previous researchers to investigate stumpage prices are mainly reflected in different driving factors and regression coefficients. These differences can be attributed primarily to variations in regional market environments and data characteristics. The novelty of forestry exchange markets, small sample sizes, and incomplete data are primary reasons explaining the dearth of studies on stumpage prices in China. However, a review of stumpage prices would shed light on changes in the trend of stumpage prices and advance understanding of the main factors that positively or negatively affect stumpage prices and forest assets in different regions of China. This will allow the values of standing trees to be evaluated and predicted.

The HPM can be used to construct a quality-adjusted price index (a hedonic price index) that reflects the price change trend and the degree of change. This index reveals the supply and demand relationship 
within a market. Traditional indexes that depend on mean or median prices may be less accurate and robust when applied to heterogeneous goods. The hedonic price index is an appropriate index for use with heterogeneous commodities and has been widely applied within the real estate [39-43] and art [44-46] markets, and in relation to products such as computers [47-49] that reflect rapid technological changes. This index can be implemented using different approaches, for example, the dummy time hedonic (DTH) index and the hedonic imputation (HI) index [50-53]. The dummy time method is the original approach used to construct a quality-adjusted price index and has a wide range of applications, whereas the imputation method entails the application of standard price index formulas, such as the Laspeyres and Paasche indexes. Since China has an active timber market and its timber products have standard specifications, a price index could be compiled using traditional methods. A state-level price index, based on the Guangdong Yuzhu International Timber Market-China's largest market for timber products-was published in 2012. However, because standing trees are heterogeneous commodities and the forestry exchange market is relatively new, an index for stumpage prices remains to be established. The compilation of such an index can advance understanding of the change trend relating to stumpage prices. However, computation of the Laspeyres and Paasche price indexes is difficult to perform in the context of stumpage. Therefore, in this study, we applied the dummy time method to construct a quality-adjusted stumpage price index.

Chinese fir is one of the most important fast-growing tree species in China. At present, the area of Chinese fir plantations is $17 \times 10^{6}$ ha, accounting for $24 \%$ of China's planted forest area [54]. As the most important timber species in southern China, the Chinese fir timber forest is the main transaction target of the forestry exchange market in this region. In the current management process, due to the emphasis on fast-growth, high-yield, and intensive management, Chinese fir timber forests are often single species structures.

This study had the following primary objectives. The first was to establish a model for forecasting the stumpage prices of Chinese fir timber forests and to compile sequential price and base price indexes for the stumpage prices of Chinese fir timber forests. The second was to elucidate the changing trend for stumpage prices over a 10-year period and to analyze the relationship between stumpage prices and the sales characteristics of Chinese fir timber forests. The third and final objective was to compare the price changes in the forestry exchange markets and the timber markets and to evaluate the uncertainty and risks associated with these two markets.

\section{Materials and Methods}

\subsection{Data Collection}

China's forestry exchange markets entail two forms of trading: floor trading and over-the-counter trading. Whereas statistics on over-the-counter trading were difficult to procure, we were able to obtain relatively comprehensive information on trading volumes and the amount of floor trading. The floor trading data presented in this paper were obtained from the South China and East China Forestry Exchanges, both of which are primary markets for forest trading in collective forest areas in Southern China. These forests are located within a vast expanse of land stretching from south of Qinling and Huaihe to east of the Yunnan-Guizhou Plateau. This region encompasses 10 provinces: Hunan, Hubei, Jiangxi, Anhui, Zhejiang, Fujian, Guangdong, Guangxi, Hainan, and Guizhou. The forested area is characterized by a warm climate, abundant rainfall, good plant growth conditions, and a wide variety of tree species. The main tree species found within plantation forests are Chinese fir and Masson pine. This region is China's main wood production base, accounting for $37.12 \%$ of the country's forest area. Most of the forests and forest land in Southern China are collectively owned.

The floor trading data from the forestry exchange markets included region, project type, ownership type, stand structure, stand age, stand stock volume, forest species, transfer period, forest land area, transaction date, and transaction price (Table 1). However, because China's forestry exchange markets were in the initial stage of development, many transaction data were incomplete. 
Table 1. Illustrative sales data procured from forestry exchange markets in China.

\begin{tabular}{|c|c|c|}
\hline Fields & Expected Sign & Examples \\
\hline Location & & $\begin{array}{c}\text { Chengjia Dock, Fangpo Village, } \\
\text { Suzhuang Town, Kaihua County, Quzhou City, } \\
\text { Zhejiang Province. }\end{array}$ \\
\hline Type & & Ownership of standing trees \\
\hline Ownership & & Collective ownership \\
\hline $\begin{array}{l}\text { Distance to nearest simple road } \\
\qquad(\mathrm{km})\end{array}$ & - & 40 \\
\hline $\begin{array}{l}\text { Distance to nearest national, } \\
\text { provincial or county roads }(\mathrm{km})\end{array}$ & - & 20 \\
\hline Structure & $+/-$ & $70 \%$ Chinese fir $+30 \%$ Masson pine \\
\hline Age (year) & + & 20 \\
\hline Age group & + & mature age \\
\hline Category & $+/-$ & timber forest \\
\hline Transfer period (year) & $+/-$ & 5 \\
\hline Area (ha) & $+/-$ & 11.67 \\
\hline $\begin{array}{l}\text { The average diameter at breast } \\
\text { height }(\mathrm{cm})\end{array}$ & + & 17.4 \\
\hline The average high $(\mathrm{m})$ & + & 12.5 \\
\hline Volume $\left(\mathrm{m}^{3)}\right.$ & + & Chinese fir-333 $\mathrm{m}^{3}$, Masson pine- $143 \mathrm{~m}^{3}$, total- 476 \\
\hline Total price $\left(10^{4} \mathrm{RMB}\right)$ & & 18.7 \\
\hline Transaction date & & 2017.7.21 \\
\hline
\end{tabular}

The trading assets of the South China and East China Forestry Exchanges were mainly located in collective forest areas within Southern China (Figure 1). Within this region, Jiangxi Province accounted for the highest number of trading transactions that mostly involved standing trees, followed by the provinces of Zhejiang and Hunan. Although the number of deals has increased, China's forestry exchange markets are still in their infancy and are likely to remain so for a long period of time. Consequently, issues such as nonstandard, incomplete, and untimely information disclosure arose especially during the initial years. In many cases, only limited information on, for example, the time of the trading, trading volume, stand age, forest land area, and total stock volume was procured. In recent years, a gradual improvement in the recording and standardization of information in China's forestry exchange markets has been evident. In some instances, important location information, such as location maps and the distances of forests from simple forest, national, and provincial roads have also been noted. However, records that contain complete transaction information are still relatively sparse.

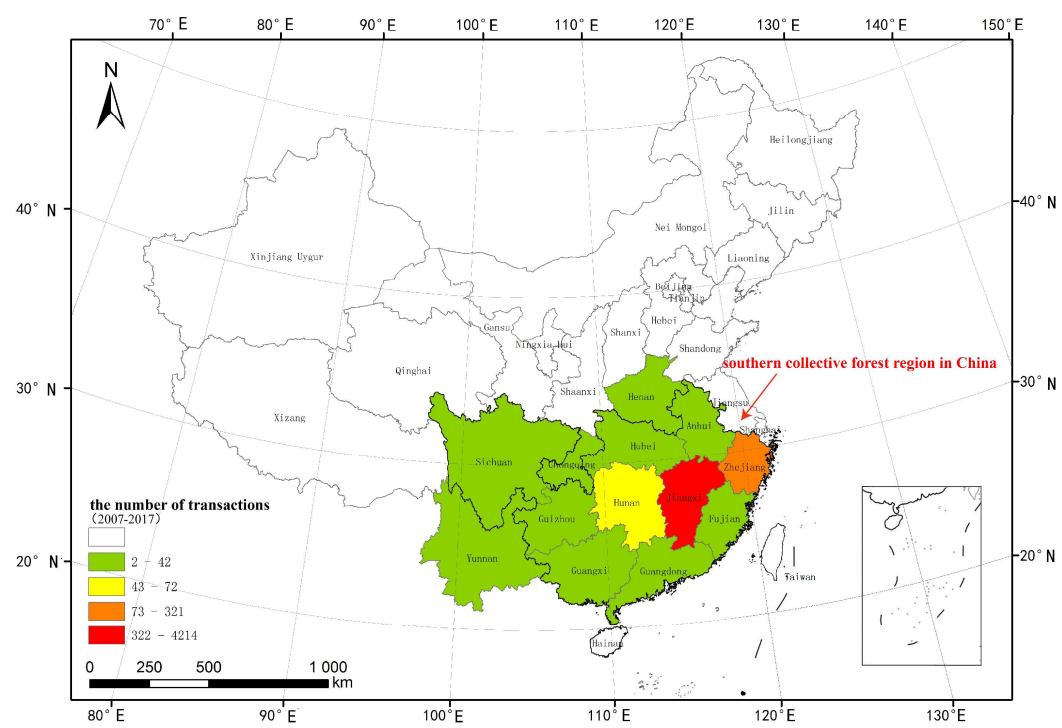

Figure 1. A map showing the distribution of sales transactions in China. 


\subsection{Hedonic Price Method}

The HPM was first introduced by Waugh [55] and began to attract serious attention in the 1970s [56]. Rosen [57] proposed a comprehensive theoretical framework for analyzing hedonic pricing in 1974. This framework enabled the relationship between price and commodity characteristics to be clarified and led to the formulation of a theoretical system for analyzing heterogeneous products. The HPM is based on the premise that the price of a good is related to its characteristics or to the services that it provides. It enables the implied value of characteristics to be estimated from the value of the price of goods using regression analysis. The following hedonic price model, entailing a dummy time element was applied in this study:

$$
P_{t}=\beta_{0}+\beta_{t} d_{t}+\sum_{k=1}^{m} \beta_{k} x_{k}+\varepsilon
$$

where, $P_{t}$ denotes the price for time period $t, \beta_{0}$ is an estimate of the constant, $\beta_{t}$ is the coefficient estimate of the time variable that directly reflects the impacts of changes in prices over time, and $d_{t}$ is the dummy time variable. When $t$ is the base period, $d_{t}=0$; when $t$ is the reporting period, $d_{t}=1$. $\beta_{k}$ is the coefficient estimate of a characteristic $k(1, \ldots, \mathrm{m}), x_{k}$ is a characteristic $k(1, \ldots, \mathrm{m})$, and $\varepsilon$ is the error term component.

The linear form of the model is the most widely used form. However, quantitative dependence among variables is commonly encountered in attempts to model actual social and economic activities and is expressed as non-linear equations. Therefore, in addition to the basic linear form, logarithmic and semi logarithmic functions were also expressed. The three basic forms of the model are as follows:

(1) Linear form:

$$
P_{t}=\beta_{0}+\beta_{t} d_{t}+\sum_{k=1}^{m} \beta_{k} x_{k}+\varepsilon
$$

In Equation (2), the independent and dependent variables are inserted into the linear form of the model, and the regression coefficient corresponds to the price of the feature.

(2) Semi logarithmic form:

$$
\ln P_{t}=\beta_{0}+\beta_{t} d_{t}+\sum_{k=1}^{m} \beta_{k} x_{k}+\varepsilon
$$

In Equation (3), the independent variable is linear, the dependent variable is logarithmic, and the regression coefficient corresponds to the rate of price change.

(3) Double logarithmic form:

$$
\ln P_{t}=\beta_{0}+\beta_{t} d_{t}+\sum_{k=1}^{m} \beta_{k} \ln x_{k}+\varepsilon
$$

In Equation (4), the independent and dependent variables are inserted into the model as logarithms, and the regression coefficient corresponds to the price elasticity of these features. Thus, providing that other features remain unchanged, for every one percentage point change in a feature variable, there will be a corresponding change in the characteristic price.

\subsection{Dummy Time Hedonic Index}

The DTH index is an approach used to estimate price changes. Compared with the HI index, the DTH index does not require a matched sample [50]. The DTH index is established on the basis 
of a hedonic price model. While excluding the influence of changes in feature variables on the price, this index reflects changes in the market price that are associated with the passage of time. Since this method requires a constant time interval to be maintained between the base period and the reporting periods that are not overly long, we constructed the price index with annual data.

The sequential price index and the base price index were constructed as follows:

(1) Sequential price index:

$$
I_{t}=e^{\hat{\beta_{t}}}
$$

(2) Base price index:

$$
I_{t}^{\prime}=I_{t} \times I_{t-1} \times I_{t-2} \cdots \cdots \times I_{1}
$$

where, $I_{t}$ is the $t$-period sequential price index, $I_{t}^{\prime}$ is the $t$-period base price index, and $\hat{\beta}_{t}$ is a parameter estimate in the hedonic price model.

\section{Results}

\subsection{Actual Stumpage Prices of Chinese Fir Timber Forests}

After we had excluded incomplete and abnormal data, a total of 928 completed sales transactions of pure Chinese fir timber forests remained for inclusion in the analysis. Since there were significant variations in the prices of standing trees of different ages, we divided the tree age into six groups according to group distance $d=10$ (Table 2). The statistical results indicated that the trading volume in the 20-30 group was the greatest, followed by the 10-20 and 30-40 groups. The average prices per cubic meter and per hectare were $599.52 \mathrm{yuan} / \mathrm{m}^{3}$ and $4483.37 \mathrm{yuan} / \mathrm{ha}$ respectively. Compared with the price per unit area (yuan/ha), the price per unit volume $\left(\mathrm{yuan} / \mathrm{m}^{3}\right.$ ) was more discrete, with more outliers occurring in the $20-30$ and $30-40$ groups (Figure 2 ).

\begin{tabular}{|c|c|c|c|c|}
\hline \multirow{2}{*}{$\begin{array}{l}\text { Age Group } \\
\text { (year) }\end{array}$} & \multirow{2}{*}{\multicolumn{2}{|c|}{ Trading Volume (case) }} & \multicolumn{2}{|c|}{ Average Price } \\
\hline & & & $\begin{array}{l}\text { Unit Stock Price } \\
\left(\text { yuan } / \mathrm{m}^{3}\right)\end{array}$ & $\begin{array}{c}\text { Unit Area Price } \\
\text { (yuan/ha) }\end{array}$ \\
\hline $0-10$ & \multicolumn{2}{|c|}{13} & 574.6199 & 2638.0159 \\
\hline $10-20$ & \multicolumn{2}{|c|}{142} & 714.6930 & 4872.8164 \\
\hline $20-30$ & \multicolumn{2}{|c|}{601} & 599.5162 & 4483.3684 \\
\hline $30-40$ & \multicolumn{2}{|c|}{161} & 736.7439 & 6571.9358 \\
\hline $40-50$ & \multicolumn{2}{|c|}{10} & 689.4719 & 6699.8284 \\
\hline other & \multicolumn{2}{|c|}{1} & 901.4534 & 12404.0000 \\
\hline total & \multicolumn{2}{|c|}{928} & 641.8940 & 4911.8777 \\
\hline \multirow{2}{*}{$\begin{array}{l}\text { Age Group } \\
\text { (year) }\end{array}$} & \multicolumn{2}{|c|}{ Unit Stock Price (yuan/m $\mathbf{m}^{3}$ ) } & \multicolumn{2}{|c|}{ Unit Area Price (yuan/ha) } \\
\hline & $\min$ & $\max$ & $\min$ & $\max$ \\
\hline $0-10$ & 206.0687 & 1056.4235 & 162.4129 & 6442.8945 \\
\hline $10-20$ & 106.6666 & 1418.4397 & 147.3414 & $13,157.8947$ \\
\hline $20-30$ & 131.1991 & 2500.0000 & 284.3601 & $54,545.4545$ \\
\hline $30-40$ & 233.3816 & 1700.5128 & 982.3736 & $17,439.3305$ \\
\hline $40-50$ & 98.4009 & 1260.6599 & 487.8048 & $20,000.0000$ \\
\hline other & 901.4534 & 901.4534 & $12,404.0000$ & $12,404.0000$ \\
\hline Total & 98.4009 & 2500.0000 & 147.3414 & $54,545.4545$ \\
\hline
\end{tabular}

Table 2. Unit prices of forests of Chinese fir timber belonging to different age groups. 


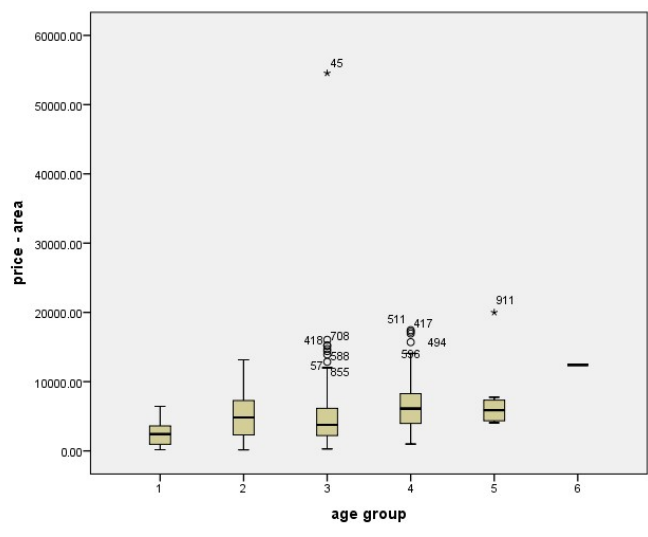

(a) Unit area prices

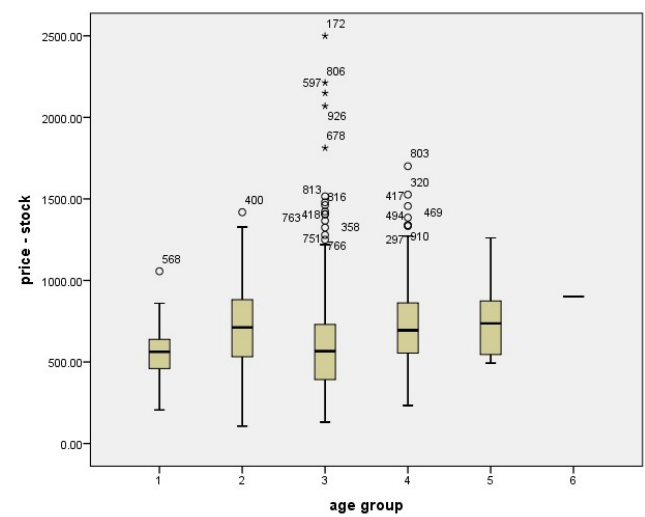

(b) Unit stock prices

Figure 2. Box plots of unit prices of forests of Chinese fir trees by area (a) and stock (b).

\subsection{Selection of a Hedonic Price Model for Chinese Fir Timber Forests}

At the time of our study, China's forestry exchange market was at a nascent developmental stage, characterized by insufficient competition and incomplete information disclosure. Constraints relating to data collection made it impossible to construct a hedonic price model that included all of the characteristic variables. However, a preliminary analysis could still be performed using existing data. Whereas the available data on stand ages, forest land areas, and stock volumes were definite and complete, other indexes, such as the average diameter at breast height (DBH), average tree height, and distance to the nearest road were often absent. Therefore, we only included the three definite variables in our study.

Considering the actual transaction price (i.e., the total price) as a dependent variable and the stand age, forest land area, and total stock volume as independent variables, the linear, semi logarithmic, and double logarithmic forms were used for the estimations. The results of the analysis indicated that there was a high goodness of fit for the linear and double logarithmic models $\left(R^{2}\right.$ ad $\left.\geq 80 \%\right)$, whereas the $R^{2}$ ad of the semi logarithmic model was only $27.8 \%$, indicating a relatively low goodness of fit (Table 3; Table 4. In the linear and double logarithm models, the variable of forest land area failed to pass the significance test. The prediction effect and accuracy of the three forms were evaluated using the standard error. The results showed that the prediction error of the double logarithm form was the smallest. To further analyze the prediction effect of the double logarithm form, data on 30 cases outside the model were used for prediction in this paper. An independent sample $t$-test was carried out on the two groups of data of the actual stumpage price and the predicted stumpage price (Table 5). The results showed that $p>0.05$, indicating that there was no significant difference between the mean values of the two groups.

Table 3. Model setting. Sig.: significance.

\begin{tabular}{ccccccc}
\hline Model & & SS & df & MS & F & Sig. \\
\hline \multirow{2}{*}{1} & Regression & $8,381,455.863$ & 3 & $2,793,818.621$ & 2109.826 & $0.000^{* * *}$ \\
\cline { 2 - 7 } & Residuals & $1,185,153.470$ & 895 & 1324.194 & & \\
\cline { 2 - 7 } & Total & $9,566,609.333$ & 898 & & & \\
\hline \multirow{2}{*}{2} & Regression & 352.851 & 3 & 117.617 & 116.412 & $0.000^{* * *}$ \\
\cline { 2 - 7 } & Residuals & 904.267 & 895 & 1.010 & & \\
\cline { 2 - 7 } & Total & 1257.117 & 898 & & & \\
\hline \multirow{3}{*}{3} & Regression & 1071.793 & 3 & 357.264 & 1725.365 & $0.000^{* * *}$ \\
\cline { 2 - 7 } & Residuals & 185.324 & 895 & 0.207 & & \\
\cline { 2 - 7 } & Total & 1257.117 & 898 & & & \\
\hline
\end{tabular}

Notes: (1) Models 1, 2, and 3 represent linear, semi logarithmic, and double logarithmic models, respectively. (2) ${ }^{* * *} p \leq 0.001$. 
Table 4. Model statistical test.

\begin{tabular}{|c|c|c|c|c|c|c|c|}
\hline \multirow{2}{*}{ Model } & & \multicolumn{5}{|c|}{ Coefficients } & \\
\hline & & B & Std. Error & Beta & $t$ & Sig. & \\
\hline \multirow{4}{*}{1} & Constant & 7.007 & 3.331 & & 2.104 & 0.036 & \multirow{4}{*}{$\begin{array}{c}\mathrm{R}^{2} \mathrm{ad}=0.876 \\
\text { Std. Error }=36.389\end{array}$} \\
\hline & Age & 0.516 & 0.126 & 0.048 & 4.093 & $0.000 * * *$ & \\
\hline & Volume & 0.045 & 0.001 & 0.916 & 58.696 & $0.000 * * *$ & \\
\hline & Area & 0.008 & 0.005 & 0.022 & 1.426 & 0.154 & \\
\hline \multirow{4}{*}{2} & Constant & 3.024 & 0.092 & & 32.873 & 0.000 & \multirow{4}{*}{$\begin{array}{c}\mathrm{R}^{2} \mathrm{ad}=0.278 \\
\text { Std. Error }=1.005\end{array}$} \\
\hline & Age & 0.014 & 0.003 & 0.116 & 4.085 & $0.000 * * *$ & \\
\hline & Volume & 0.000 & 0.000 & 0.381 & 10.122 & $0.000 * * *$ & \\
\hline & Area & 0.001 & 0.001 & 0.172 & 4.589 & $0.000^{* * *}$ & \\
\hline \multirow{4}{*}{3} & Constant & -3.439 & 0.146 & & -23.626 & 0.000 & \multirow{4}{*}{$\begin{array}{c}\mathrm{R}^{2}{ }_{\mathrm{ad}}=0.852 \\
\text { Std. Error }=0.455\end{array}$} \\
\hline & Age & -0.023 & 0.038 & -0.008 & -0.591 & 0.555 & \\
\hline & Volume & 1.102 & 0.027 & 0.932 & 40.969 & $0.000^{* * *}$ & \\
\hline & Area & -0.010 & 0.026 & -0.009 & -0.396 & 0.692 & \\
\hline
\end{tabular}

Table 5. Independent sample $t$-test for Model 3.

\begin{tabular}{ccccc}
\hline Group & $\mathbf{N}$ & Mean & Std. Deviation & Std. Error Mean \\
\hline $\mathbf{1}$ & 30 & 3.1614 & 1.1510 & 0.2101 \\
$\mathbf{2}$ & 30 & 3.5895 & 1.0194 & 0.1861 \\
\hline & $t$ value & $\mathrm{df}$ & Sig.(2-tailed) & \\
& -1.525 & 58 & 0.133 & \\
\hline
\end{tabular}

Notes: Group $1=\ln$ (actual stumpage price), Group $2=\ln$ (predicted stumpage price).

\subsection{Determination of the Hedonic Price Method for Chinese Fir Timber Forests}

In the equations expressing the linear and double logarithmic models, the influence of forest land area on price was not significant. We, therefore, excluded this variable. The nature and correlation of data did not change following the inclusion of logarithms, but the scale of the variable was compressed, and the data were found to be more stable. Consequently, we selected the model with the double logarithm form. The predictive models, entailing a dummy time element were established on the basis of continuous annual data obtained for the period 2007-2016 (Table 6).

The results obtained using this model indicated that the stock volume had a significant impact on stumpage prices, and the $p$-value of the regression coefficient significance test conducted for each year was less than 0.001 . The influence of stand age on stumpage prices was small, but it gradually increased and became significant after 2011. Apart from the characteristic variables, the transaction timing, especially within models constructed in 2010 and 2015, also affected the stumpage prices. The result of the regression coefficient test for the dummy time variable was $p<0.001$, indicating a drastic change in the price compared with the changes in 2009-2010 and 2014-2015. The changes in the $R^{2}$ ad and standard error values reflected improvements in the model. Specifically, the predictions estimated closer points in time, revealing that the Chinese fir stumpage prices were gradually returning to rational values with the introduction of the Chinese forestry exchange market, and gradually progressing toward standardization. 
Table 6. The annual forecast model.

\begin{tabular}{|c|c|c|}
\hline Year & Model & Test \\
\hline 2008 & $\begin{array}{c}\ln \hat{P}_{2008}=-4.346+0.155 \mathrm{~d}_{2008}+0.097 \text { lnage }+1.093 \text { lnstock } \\
\quad \mathrm{t}=(-11.263)(1.730)(0.988)(34.455)\end{array}$ & $\begin{array}{c}n=170 \\
\operatorname{sigF}=0.000 * * \\
\mathrm{R}^{2} \text { ad }=88 \% \\
\text { Std.Error }=0.414\end{array}$ \\
\hline 2009 & $\begin{array}{c}\ln \hat{P}_{2009}=-4.116+0.059 d_{2009}+0.027 \text { lnage }+1.114 \text { lnstock } \\
\quad t=(-9.427)(0.996)(0.206)(35.535)\end{array}$ & $\begin{array}{c}n=260, \\
\operatorname{sigF}=0.000 * * * \\
\mathrm{R}^{2} \text { ad }=83.8 \%, \\
\text { Std.Error }=0.462\end{array}$ \\
\hline 2010 & $\begin{array}{c}\ln \hat{P}_{2010}=-3.562+0.588 d_{2010}-0.027 \text { lnage }+1.060 \text { lnstock } \\
\quad t=(-11.502)(8.560)(-0.346)(29.802)\end{array}$ & $\begin{array}{c}n=207, \\
\operatorname{sigF}=0.000 * *, \\
\mathrm{R}^{2} \text { ad }=86.5 \%, \\
\text { Std.Error }=0.446\end{array}$ \\
\hline 2011 & $\begin{array}{c}\ln \hat{P}_{2011}=-2.494-0.040 d_{2011}+0.020 \text { lnage }+0.969 \text { lnstock } \\
\quad t=(-11.330)(-0.839)(0.459)(36.965)\end{array}$ & $\begin{array}{c}n=200 \\
\text { sigF }=0.000 * * \\
\mathrm{R}^{2}{ }_{\mathrm{ad}}^{* *}=87.5 \%, \\
\text { Std. Error }=0.333\end{array}$ \\
\hline 2012 & $\begin{aligned} \ln \hat{P}_{2012}= & -2.381-0.001 d_{2012}-0.097 \text { lnage }+0.998 \text { lnstock } \\
& t=(-14.552)(-0.032)(-2.483)(50.935)\end{aligned}$ & $\begin{array}{c}n=276, \\
\operatorname{sigF}=0.000 * * \\
\mathrm{R}^{2} \mathrm{ad}=90.6 \% \\
\text { Std. Error }=0.308\end{array}$ \\
\hline 2013 & $\begin{array}{c}\ln \hat{P}_{2013}=-2.608+0.077 d_{2013}-0.147 \text { lnage }+1.053 \text { lnstock } \\
\quad t=(-15.591)(1.975)(-3.257)(56.460)\end{array}$ & $\begin{array}{c}n=249 \\
\operatorname{sigF}=0.000^{* * *} \\
\mathrm{R}^{2}{ }_{\mathrm{ad}}=93 \\
\text { Std. Error }=0.283\end{array}$ \\
\hline 2014 & $\begin{array}{c}\ln \hat{P}_{2014}=-3.389+0.071 \mathrm{~d}_{2014}+0.184 \text { lnage }+1.021 \text { lnstock } \\
\mathrm{t}=(-13.027)(1.554)(2.319)(43.665)\end{array}$ & $\begin{array}{c}n=148 \\
\operatorname{sigF}=0.000 * * \\
\mathrm{R}^{2} \text { ad }=93.8 \% \\
\text { Std. Error }=0.272\end{array}$ \\
\hline 2015 & $\begin{array}{c}\ln \hat{P}_{2015}=-3.534-0.288 d_{2015}+0.343 \text { lnage }+0.9751 \text { lnstock } \\
\quad t=(-8.913)(-6.180)(2.861)(38.544)\end{array}$ & $\begin{array}{c}n=114 \\
\operatorname{sigF}=0.000 * * \\
\mathrm{R}^{2}{ }_{\mathrm{ad}}^{* *}=93.7 \%, \\
\text { Std. Error }=0.246\end{array}$ \\
\hline 2016 & $\begin{array}{c}\ln \hat{P}_{2016}=-5.044+0.058 d_{2016}-0.698 \text { lnage }+0.982 \text { lnstock } \\
t=(-9.365)(1.136)(4.252)(37.748)\end{array}$ & $\begin{array}{c}n=98, \\
\operatorname{sigF}=0.000^{* * *}, \\
\mathrm{R}^{2}{ }_{\mathrm{ad}}=94.3 \%, \\
\text { Std. Error }=0.251\end{array}$ \\
\hline
\end{tabular}

In addition, the model was tested for economic significance. Taking the model of 2016 as an example, the price elasticity of the stock volume was 0.982 , that is, for every $1 \%$ increase in the stock volume, the average stumpage price increased by $0.982 \%$, and the price elasticity of the stand age was 0.698 , that is, every $1 \%$ increase in stand age, the stumpage price increased by $0.698 \%$ on average. The coefficient symbol and size were in line with expectations.

In order to further explain the influence of the change of these two variables on the change of stumpage price, this paper selected the most recent predicted model, namely the model of 2016 (see Table 6), to carry out the single factor sensitivity analysis on the stock volume and stand age. Among the 928 sample data, the value range of stock volume was $(51,600,[17])$ while the stand age range was $[1,44]$. The mean of stock volume was close to $1200 \mathrm{~m}^{3}$ while that of the stand age was close to 20 years. Hence, the stock volume was fixed at the level of $1200 \mathrm{~m}^{3}$, the stumpage prices at a stand age of $5,10, \ldots, 35$, and 40 (8 groups in total) were predicted and the sensitivity coefficients of stand age were calculated. In the meantime, the stand age was fixed at the level of 20 years, the stumpage prices when the stock volume was 5000, 10,000,..., 45,000, and 50,000 (10 groups in total) were predicted and the sensitivity coefficients of stock volume were calculated ( Table 7; Table 8). The results showed that compared with the stand age, the stumpage price was more sensitive to the stock volume and the stock volume was a very important factor affecting the stumpage price. 
Table 7. Sensitivity analysis of stock volume.

\begin{tabular}{cccccc}
\hline Age (year) & Stock $\left.\mathbf{( m}^{\mathbf{3}}\right)$ & $\Delta$ Stock/Stock & Price $\left(\mathbf{1 0}^{\mathbf{4}}\right.$ yuan) & $\Delta$ Price/Price & Sensitivity \\
\hline 20 & 5000 & - & 237.20 & - & - \\
20 & 10,000 & 1 & 468.52 & 0.98 & 0.98 \\
20 & 15,000 & 2 & 697.67 & 1.94 & 0.97 \\
20 & 20,000 & 3 & 925.42 & 2.90 & 0.97 \\
20 & 25,000 & 4 & 1152.14 & 3.86 & 0.97 \\
20 & 30,000 & 5 & 1378.03 & 4.81 & 0.96 \\
20 & 35,000 & 6 & 1603.25 & 5.76 & 0.96 \\
20 & 40,000 & 7 & 1827.89 & 6.71 & 0.96 \\
20 & 45,000 & 8 & 2052.02 & 7.65 & 0.96 \\
20 & 50,000 & 9 & 2275.70 & 8.59 & 0.95 \\
\hline
\end{tabular}

Notes: $\Delta$ Stock $/$ Stock $=\left(\right.$ Stock $_{\mathrm{i}}-$ Stock $\left._{1}\right) /$ Stock $_{1}, \Delta$ Price $/$ Price $=\left(\right.$ Price $_{\mathrm{i}}-$ Price $\left._{1}\right) /$ Price $_{1}, \mathrm{i}=2,3, \ldots, 10$. Sensitivity $=$ $(\triangle$ Price $/$ Price $) /(\triangle$ Stock $/$ Stock $)$.

Table 8. Sensitivity analysis of stand age.

\begin{tabular}{cccccc}
\hline Age (year) & Stock $\left.\mathbf{( m}^{\mathbf{3}}\right)$ & $\Delta$ Age/Age & Price $\mathbf{( \mathbf { 1 0 } ^ { \mathbf { 4 } } \text { yuan) }}$ & $\Delta$ Price/Price & Sensitivity \\
\hline 5 & 1200 & - & 22.19 & - & - \\
10 & 1200 & 1 & 36.01 & 0.62 & 0.62 \\
15 & 1200 & 2 & 47.78 & 1.15 & 0.58 \\
20 & 1200 & 3 & 58.41 & 1.63 & 0.54 \\
25 & 1200 & 4 & 68.25 & 2.08 & 0.52 \\
30 & 1200 & 5 & 77.52 & 2.49 & 0.50 \\
35 & 1200 & 6 & 86.32 & 2.89 & 0.48 \\
40 & 1200 & 7 & 94.75 & 3.27 & 0.47 \\
\hline
\end{tabular}

Notes: $\triangle$ Age/Age $=\left(\right.$ Age $_{i}-$ Age $\left._{1}\right) /$ Age $_{1}, \Delta$ Price $/$ Price $=\left(\right.$ Price $_{i}-$ Price $\left._{1}\right) /$ Price $_{1}, i=2,3, \ldots, 8$. Sensitivity $=$ $(\triangle$ Price/Price $) /(\triangle$ Age $/$ Age $)$.

\subsection{Index of Stumpage Prices of Chinese Fir Timber Forests}

The DTH index was used to compile sequential and base price indexes for Chinese fir timber forests. The results of the study revealed that the price of these forests changed significantly in 2010 and 2015. The price index in 2015 was $74.95 \%$, implying that the price in 2015 decreased on average by $25.05 \%$ compared with the price in 2014 . The price index in 2010 was $180.01 \%$, implying that the price in 2010 increased by 80.01\% on average compared with the price in 2009 (Table 9, Figure 3). Taking 2007 as the base period for calculating the base price index of Chinese fir timber forests, $\mathrm{I}_{2016}=197.00 \%$, indicating that the price in 2016 had increased by $97 \%$ compared with the price in 2007 , evidencing an average annual growth rate of $7.82 \%\left(197.00 \%^{1 / 9}-1\right)$.

Table 9. The Stumpage Price Index of Chinese fir timber forests.

\begin{tabular}{cccc}
\hline Year & $\hat{\boldsymbol{\beta}}_{\boldsymbol{t}}$ & $\boldsymbol{I}_{\boldsymbol{t}}$ (Sequential) & $\boldsymbol{I}_{\boldsymbol{t}}$ (Base- 2007) \\
\hline 2016 & 0.058 & $105.99 \%$ & $197.00 \%$ \\
2015 & -0.288 & $74.95 \%$ & $185.87 \%$ \\
2014 & 0.071 & $107.36 \%$ & $247.99 \%$ \\
2013 & 0.077 & $107.99 \%$ & $230.99 \%$ \\
2012 & -0.001 & $99.87 \%$ & $213.90 \%$ \\
2011 & -0.04 & $96.08 \%$ & $214.18 \%$ \\
2010 & 0.588 & $180.01 \%$ & $222.92 \%$ \\
2009 & 0.059 & $106.07 \%$ & $123.84 \%$ \\
2008 & 0.155 & $116.75 \%$ & $116.75 \%$ \\
\hline
\end{tabular}




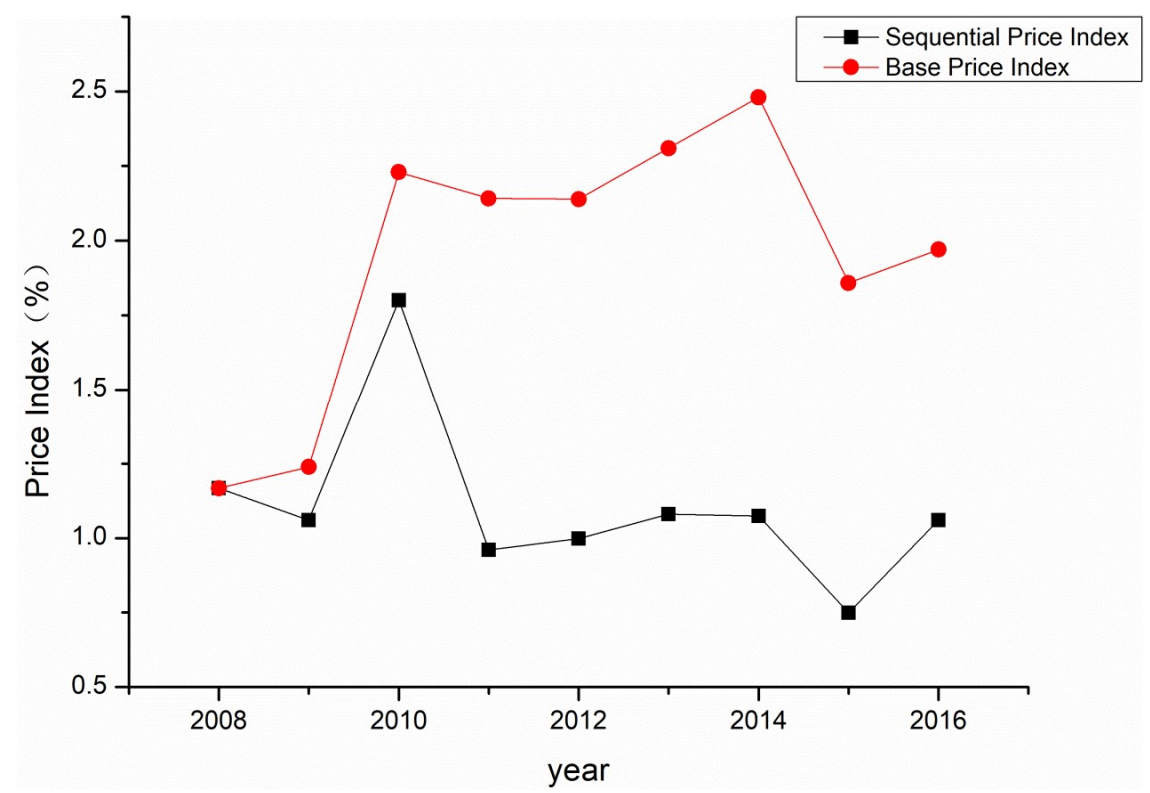

Figure 3. The chart of the stumpage price index of Chinese fir timber forests.

\section{Discussion}

\subsection{Choice of HPM Form}

Since variables with different scales as well as dummy variables were selected, we needed to find the optimal model form, e.g., linear, semi logarithmic, double logarithmic, or other forms. No one form is the best for every situation. The best form depends on which is more suitable for your actual situation $[58,59]$. Previous studies on the stumpage price have generally adopted the linear form of HPM [15,37]. In this paper, the linear form also had a good predictive power, but the model comparison revealed that the double logarithmic form was best suited for our research.

\subsection{Factors Driving Stumpage Prices of Chinese Fir Timber Forests}

Stock volume was the key driver of stumpage prices of Chinese fir. Munn et al. [60] found that when stumpage values were positive, the predicted signs of the coefficients of volume variables were all positive. Our results indicated that there was a strong positive correlation between stock volume and the stumpage prices of Chinese fir. The effects of forest management are ultimately reflected in tree volume and growth. If the volume of a stand is high, then the forest harvest and corresponding incomes of forest farmers will be high. Therefore, the value of forest assets is mainly reflected in the value of trees. In addition, while China's forest law allows for the mortgage of timber forests, a forest asset evaluation must first be conducted. The valuation of standing trees is mainly conducted using two methods: the replacement cost method and the present value of benefits method. While the former is only applicable to young forests, the latter is applicable to stands of other ages, and the main parameter used is the stock volume.

The effect of stand age on the stumpage prices of Chinese fir was less than that of stock volume, and there was also a positive correlation between stand age and stumpage price. Zhang et al. [61] found that the age of pine had a significant impact on the price of timber stands. In timber forests, volume growth, which is closely related to tree height and DBH, is an important index of stand quality management. Average DBH and stand height are also important indexes for evaluating stand quality. According to the findings of previous studies, a close positive correlation exists between the stand age and the mean DBH, mean tree height, or basal area. Accordingly, age-height and age-DBH growth models have been established [62,63]. Stand age is an important criterion in the study of stand growth dynamics, stand biomass change, and site quality. 
The results of this study indicated that there is no correlation between the forest land area and the stumpage prices of Chinese fir. A probable reason for this finding is that our study focused on the price of standing trees and not on the forest land. From the perspective of buyers of forest assets, the purchase price is affected by the number of trees and not by the area of forest land.

\subsection{The Difference between Forestry Exchange and Timber Markets in China}

The DTH index method, which was used to compile the stumpage prices index, has practical application value. An index of stumpage prices reflects the price change degree and trend and provides a basis for establishing the price considering both buyers and sellers in the forestry exchange market. A comparison of the price change trend of standing trees in the forestry exchange market and log prices in the timber market can shed light on the differences between these two markets. Our results indicated that between 2015 and 2010, the stumpage prices of Chinese fir in the forestry exchange market changed significantly, as evidenced by price indexes of $74.95 \%$ in 2015 and $180.01 \%$ in 2010 . To compare the stumpage and log prices, we collected the annual prices of Chinese fir logs from Lechang in Guangdong Province that were $4 \mathrm{~m}$ long, with tail diameters of 5-6 cm and 9-10 cm, respectively, for the period stretching from 2007 to the end of 2016. The prices of logs with a tail diameter of 5-6 cm, expressed in yuan $/ \mathrm{m}^{3}$, were as follows: 660, 500, 600, 700, 860, 950, -, 980, 1050, and 1020 , while the prices of logs (in yuan $/ \mathrm{m}^{3}$ ) with a tail diameter of $9-10 \mathrm{~cm}$ were $750,560,700,900,960$, 1050, - , 1100, 1150, and 1120 (http://www.chinatimber.org). This comparative analysis reveals differing price changes relating to Chinese fir in the two markets. In 2015, the growth rate of the prices of logs with tail diameters of 5-6 cm and 9-10 $\mathrm{cm}$ were $7.14 \%$ and $4.55 \%$, respectively, whereas the growth rate of stumpage prices was $-25.05 \%$. In 2010, the growth rate of prices of logs with tail diameters of $5-6 \mathrm{~cm}$ and $9-10 \mathrm{~cm}$ were $16.67 \%$ and $28.57 \%$, respectively, whereas the growth rate of stumpage prices was $80.01 \%$. Thus, the forestry exchange and timber markets evidenced significant differences. The price range within the timber market was relatively small, whereas the price range within the forestry exchange market was relatively large. This finding indicates that there are more uncertain factors and risks in the forestry exchange market compared with those existing in the timber market.

\subsection{Impact on Forest Accounting}

We developed an alternative approach for estimating the market value of standing trees that differs from previous forest accounting approaches recommended within the System of Integrated Environmental and Economic Accounting (SEEA), proposed by the United Nations [64,65]. The SEEA is based on the net present value method, the stumpage value method, and the consumption value method. Whereas the net present value method is greatly influenced by the discount rate, in the latter two methods, the value of standing trees is obtained by multiplying the standing volume by the price of timber of the kind being produced and sold in the timber market. These three methods cannot reflect the stumpage market value of standing trees or provide a value scale for fair market transactions. In the context of the SEEA initiative (SEEA 2012), in 2014, the Chinese government announced that it would prepare national and local balance sheets of natural resources [66]. The purpose of these balance sheets, entailing an accounting period coinciding with the calendar year from 1 January to 31 December, was to contribute to China's efforts to promote sustainable development through an assessment of changes in the physical quantity and monetary value of natural resource assets during the year in question. However, so far, there has been no substantial progress in the preparation of natural resources balance sheets, with the accounting method posing major technical difficulties. The annual prediction model constructed in this paper provides an approach for conducting batch and periodic assessments of forest resources.

\subsection{Further Studies}

Data collection was a key constraint in the model-building process. We examined only four variables relating to stumpage prices: volume, age, area, and the time of trading and did not consider 
factors such as location, distance from adjacent roads, and cutting costs. Future studies could extend these variables by adjusting and adding other variables. Additionally, we only assessed the stumpage prices of Chinese fir timber forests, and did not examine other forest types and tree species. With the development of the forestry exchange market in China, more in-depth research will be required.

\section{Conclusions}

We investigated the change trend and driving factors of stumpage prices of Chinese fir timber forests using the HPM and DTH index. The stock volume was the most important factor, followed by the age of the stand. The area of the forest had no significant effect on the stumpage price. It should be noted that although the independent variables assessed in this study were limited, the proportion of the variation of the dependent variable that could be explained by independent variables was over $80 \%\left(R^{2}\right.$ ad $>80 \%$, which meant that the explanatory power of statistical model was strong. In addition, we found that compared with the timber market, the forestry exchange market is more volatile and uncertain. This study encompassed the perspectives of buyers as well as sellers within forestry exchange markets thus providing valuable inputs that can facilitate the efforts of the Chinese government to optimize resource allocation and direct the forestry exchange market toward standardization.

Author Contributions: Conceptualization, H.C., J.L.; Data curation, H.C.; Formal analysis, H.C.; Funding acquisition, H.C.; Investigation, H.C., Z.H.; Methodology, H.C., W.H.; Writing-original draft, H.C.; Writing-review and editing, H.C., W.H., J.L. All authors have read and agreed to the published version of the manuscript.

Funding: This research was funded by the Fujian Education and Scientific Research Program for young and middle-aged teachers (No.KLA19025A) and Science and Technology Innovation Project of Fujian Agricultural and Forestry University (No.KFA18038A).

Acknowledgments: We wish to thank Zhong-ming Teng and Chun-yan Lu for helpful discussions and valuable suggestions during the revision of the manuscript. We thank Radhika Johari from Liwen Bianji, Edanz Editing China (www.liwenbianji.cn/ac), for editing the English text of a draft of this manuscript. The authors also express sincere appreciation for helpful and constructive comments provided by the three reviewers of the draft manuscript.

Conflicts of Interest: The authors declare no conflict of interest. The funders had no role in the design of the study; in the collection, analyses, or interpretation of data; in the writing of the manuscript, or in the decision to publish the results.

\section{References}

1. Wagner, J.E.; Sendak, P.E. The annual increase of Northeastern regional timber stumpage prices: 1961 to 2002. For. Prod. J. 2005, 55, 36-45.

2. Howard, T.E.; Chase, W.E. Maine stumpage prices: Characteristics and trends from 1963 to 1990. For. Prod. J. 1995, 45, 31-36.

3. Linehan, P.E.; Jacobson, M.G.; McDill, M.E. Hardwood Stumpage Price Trends and Regional Market Differences in Pennsylvania. North. J. Appl. For. 2003, 20, 124-130. [CrossRef]

4. Linehan, P.E.; Jacobson, M.G. Forecasting hardwood stumpage price trends in Pennsylvania. For. Prod. J. 2005, 55, 47-52.

5. Mei, B.; Clutter, M.; Harris, T. Modeling and forecasting pine sawtimber stumpage prices in the US South by various time series models. Can. J. For. Res. 2010, 40, 1506-1516. [CrossRef]

6. Bayazidi, S.; Yoshimoto, A. Appropriate stochastic price models for the finnish stumpage market. Formath 2011, 10, 123-142. [CrossRef]

7. Duval, R.P.; McConnell, T.E.; Hix, D.M. Annual Change in Ohio Hardwood Stumpage Prices, 1960 to 2011. For. Prod. J. 2014, 64, 19-25. [CrossRef]

8. Hultkrantz, L.; Andersson, L.; Mantalos, P. Stumpage prices in Sweden 1909-2012: Testing for non-stationarity. J. For. Econ. 2014, 20, 33-46. [CrossRef]

9. Parajuli, R.; Tanger, S.; Joshi, O.; Henderson, J. Modeling Prices for Sawtimber Stumpage in the South-Central United States. Forests 2016, 7, 148. [CrossRef]

10. Nautiyal, J.C. Stumpage price function for hardwoods in the Niagara district of Ontario. Can. J. For. Res. 1982, 12, 210-214. [CrossRef] 
11. Xu, Z.H.; McKetta, C.W. Understanding log and stumpage prices in China: A primer for capitalist forest economists. Can. J. For. Res. 1986, 16, 1123-1127. [CrossRef]

12. Sedjo, R.A. Comparative views of different stumpage pricing systems: Canada and the United States. For. Sci. 2006, 52, 446-450.

13. Niquidet, K.; van Kooten, G.C. Transaction Evidence Appraisal: Competition in British Columbia's Stumpage Markets. For. Sci. 2006, 52, 451-459.

14. Brown, R.N.; Kilgore, M.A.; Coggins, J.S.; Blinn, C.R. The impact of timber-sale tract, policy, and administrative characteristics on state stumpage prices: An econometric analysis. For. Policy Econ. 2012,21,71-80. [CrossRef]

15. Brown, R.N.; Kilgore, M.A.; Blinn, C.R.; Coggins, J.S. The impact of reserve prices and contract length on stumpage bid prices: An empirical assessment. North. J. Appl. For. 2013, 30, 85-91. [CrossRef]

16. Nepal, P.; Grala, R.K.; Grebner, D.L.; ABT, R.C. Impact of harvest-level changes on carbon accumulation and timber stumpage prices in Mississippi. South. J. Appl. For. 2013, 37, 160-168. [CrossRef]

17. Luppold, W.; Bumgardner, M.; Mcconnell, T.E. Impacts of changing hardwood lumber consumption and price on stumpage and sawlog prices in Ohio. For. Sci. 2014, 60, 994-999. [CrossRef]

18. Klepacka, A.M.; Siry, J.P.; Bettinger, P. Stumpage prices: A review of influential factors. Int. For. Rev. 2017, 19, 158-169. [CrossRef]

19. Yin, R.; Yao, S.; Huo, X. China's forest tenure reform and institutional change in the new century: What has been implemented and what remains to be pursued? Land Use Policy 2013, 30, 825-833. [CrossRef]

20. Han, X.; Kant, S.S.; Xie, Y.A. spatial hedonic stumpage analysis of standing timber auctions in Jiangxi Province of China. For. Policy Econ. 2018, 96, 63-74. [CrossRef]

21. Ladd, G.W.; Martin, M.B. Prices and demands for input characteristics. Am. J. Agric. Econ. 1976, 58, 21-30. [CrossRef]

22. Calderon, A.D.; Caudill, S.B.; Mixon, F.G. Valuing Recreational Water Clarity and Quality: Evidence from Hedonic Pricing Models of Lakeshore Properties. Appl. Econ. Lett. 2019, 26, 237-244. [CrossRef]

23. Cavallo, C.; Caracciolo, F.; Cicia, G.; Del Giudice, T. Extra-virgin olive oil: Are consumers provided with the sensory quality they want? A hedonic price model with sensory attributes. J. Sci. Food Agric. 2018, 98, 1591-1598. [CrossRef] [PubMed]

24. Ready, R.C.; Abdalla, C.W. The Amenity and Disamenity Impacts of Agriculture: Estimates from a Hedonic Pricing Model. Am. J. Agric. Econ. 2005, 87, 314-326. [CrossRef]

25. Humphreys, B.R.; Mondello, M. Determinants of Franchise Values in North American Professional Sports Leagues: Evidence from a Hedonic Price Model. Int. J. Sport. Financ. 2008, 3, 98.

26. Kwong, L.M.K.; Ogwang, T.; Sun, L. Semiparametric versus parametric hedonic wine price models: An empirical investigation. Appl. Econ. Lett. 2017, 24, 897-901. [CrossRef]

27. Van der Merwe, J.D.; Cloete, P.C.; van Schalkwyk, H.D. Factors Influencing the Competitiveness of the South African Wheat Industry: A Hedonic Price Model. Agrekon 2016, 55, 411-435. [CrossRef]

28. Yim, E.S.; Lee, S.; Kim, W.G. Determinants of a restaurant average meal price: An application of the hedonic pricing model. Int. J. Hosp. Manag. 2014, 39, 11-20. [CrossRef]

29. Wang, Z.G.; Zheng, S.; Lambert, D.M.; Fukuda, S.A. Hedonic Price Model for Rice Market in China. J. Fac. Agric. Kyushu. Univ. 2009, 54, 541-548.

30. Nepal, M.; Nepal, A.K.; Apsara; Berrens, R.P. Where gathering firewood matters: Proximity and forest management effects in hedonic pricing models for rural Nepal. J. For. Econ. 2017, 27, 28-37. [CrossRef]

31. Randeniya, T.D.; Ranasinghe, G.; Amarawickrama, S. A model to Estimate the Implicit Values of Housing Attributes by Applying the Hedonic Pricing Method. Int. J. Built. Environ. Sustain. 2017, 4, 113-120. [CrossRef]

32. Bonnetain, P. A hedonic price model for islands. J. Urban. Econ. 2003, 54, 368-377. [CrossRef]

33. Escobedo, F.J.; Adams, D.C.; Timilsina, N. Urban forest structure effects on property value. Ecosyst. Serv. 2015, 12, 209-217. [CrossRef]

34. Puttock, G.D.; Meilke, K.D.; Prescott, D.M. Stumpage prices in southwestern Ontario: A hedonic function approach. For. Sci. 1990, 36, 1119-1132.

35. Aronsson, T.; Carlén, O. The determinants of forest land prices: An empirical analysis. Can. J. For. Res. 2000, 30, 589-595. [CrossRef] 
36. Leefers, L.A.; Potter, W.K. Timber sale characteristics and competition for public Lands Stumpage: A case study from the Lake States. For. Sci. 2006, 52, 460-467.

37. Kolis, K.; Hiironen, J.; Ärölä, E.; Vitikainen, A. Effects of sale-specific factors on stumpage prices in Finland. Silva Fenn. 2014, 48. [CrossRef]

38. Kim, H.; Cieszewski, C. The Analysis of Pine Stumpage Prices Based on Timber Sale Characteristics of the Southern United States. J. For. Environ. Sci. 2015, 31, 38-46. [CrossRef]

39. Wigren, R. House Price Indexes: The Hedonic Technique, and Some Other Methods Applied to Price Movements of Single Family Houses in Sweden. Scand. Hous. Plan. Res. 1984, 1, 81-98. [CrossRef]

40. Gouriéroux, C.; Laferrère, A. Managing hedonic housing price indexes: The French experience. J. Hous. Econ. 2009, 18, 206-213. [CrossRef]

41. Du, Y.; Sun, H.Q.; Zhang, S.Y.; Tian, Q. Design of Real Estate Price Index System Based on Hedonic Price Method. Appl. Mech. Mater. 2014, 488, 1463-1466.

42. Hill, R.J. Hedonic Price Indexes for residential housing: A survey, evaluation and taxonomy. J. Econ. Surv. 2013, 27, 879-914. [CrossRef]

43. Glumac, B.; Herrera, G.M.; Licheron, J. A hedonic urban land price index. Land Use Policy 2019, 81, 802-812. [CrossRef]

44. Witkowska, D. Evaluation of the Individual Hedonic Art Price Indexes for the Polish Painters Representing the Auction Market in Poland. Transform. Bus. Econ. 2016, 15, 61-77.

45. Pradier, P.C.; Gardes, F.; Greffe, X.; Mendoza, I.M. Autographs and the global art market: The case of hedonic prices for French autographs (1960-2005). J. Cult. Econ. 2016, 40, 453-485. [CrossRef]

46. Bocart, F.; Hafner, C.M. Econometric analysis of volatile art markets. Comput. Stat. Data Anal. 2012, 56, 3091-3104. [CrossRef]

47. Berndt, E.R.; Griliches, Z.; Rappaport, N.J. Econometric estimates of price indexes for personal computers in the 1990's. J. Econom. 1995, 68, 243-268. [CrossRef]

48. Pakes, A. A reconsideration of hedonic price indexes with an application to PC's. Am. Econ. Rev. 2003, 93, 1578-1596. [CrossRef]

49. Benkard, C.L.; Bajari, P. Hedonic price indexes with unobserved product characteristics, and application to personal computers. J. Bus. Econ. Stat. 2005, 23, 61-75. [CrossRef]

50. Silver, M.; Heravi, S. The difference between Hedonic Imputation Indexes and Time Dummy Hedonic Indexes. J. Bus. Econ. Stat. 2007, 25, 239-246. [CrossRef]

51. De Haan, J. Hedonic price indexes: A comparison of imputation, time dummy and Re-Pricing methods. Jahrb. Natl. Stat. 2010, 230, 772-791.

52. De Haan, J. Direct and indirect time dummy approaches to hedonic price measurement. J. Econ. Soc. Meas. 2004, 29, 427-443. [CrossRef]

53. Hill, R.J.; Melser, D. Hedonic imputation and the price index problem: An application to housing. Econ. Inq. 2008, 46, 593-609. [CrossRef]

54. Liu, X.; Fu, Z.Y.; Zhang, B. Effects of sulfuric, nitric, and mixed acid rain on Chinese fir sapling growth in Southern China. Ecotoxicol. Environ. Saf. 2018, 160, 154-161. [CrossRef] [PubMed]

55. Waugh, F.V. Quality factors influencing vegetable prices. J. Farm. Econ. 1928, 10, 185-196. [CrossRef]

56. Griliches, Z. Price Indexes and Quality Change; Griliches, Z., Ed.; Harvard University Press: Cambridge, MA, USA, 1971; pp. 3-15.

57. Rosen, S. Hedonic prices and implicit markets: Product differentiation in pure competition. J. Polit. Econ. 1974, 82, 34-55. [CrossRef]

58. Fleischer, A. A room with a view-A valuation of the Mediterranean Sea view. Tour. Manag. 2012, 33, 598-602. [CrossRef]

59. Hamilton, J.M. Costal landscape and the hedonic price of accommodation. Ecol. Econ. 2007, 62, 594-602. [CrossRef]

60. Munn, L.A.; Palmquist, R.B. Estimating hedonic price equations for a timber stumpage market using stochastic frontier estimation procedures. Can. J. For. Res. 1997, 27, 1276-1280. [CrossRef]

61. Zhang, D.W.; Meng, L.; Polyakov, M. Determinants of the Prices of Bare Forestland and Premerchantable Timber Stands: A Spatial Hedonic Study. For. Sci. 2013, 59, 400-406. [CrossRef]

62. Zeide, B. Analysis of growth equations. For. Sci. 1993, 39, 594-616. [CrossRef] 
63. Liu, Z.; Li, F. The generalized Chapman-Richards function and application to tree and stand growth. J. For. Res. 2003, 14, 19-26.

64. Bartelmus, P. Environmental-Economic Accounting: Progress and digression in the SEEA revision. Rev. Income Wealth. 2014, 60, 887-904. [CrossRef]

65. El Serafy, S. System of Environmental-Economic Accounting 2012-Central Framework, United Nations, European Commission, Food and Agriculture Organisation of the United Nations, International Monetary Fund, Organisation for Economic Co-operation and Development and World Bank. Ecol. Econ. 2015, 112, 161-163. [CrossRef]

66. Song, M.L.; Zhu, S.; Wang, J. China's natural resources balance sheet from the perspective of government oversight: Based on the analysis of governance and accounting attributes. J. Environ. Manag. 2019, 248, 109-232. [CrossRef]

(C) 2020 by the authors. Licensee MDPI, Basel, Switzerland. This article is an open access article distributed under the terms and conditions of the Creative Commons Attribution (CC BY) license (http://creativecommons.org/licenses/by/4.0/). 